\title{
Faktor-faktor yang Berhubungan dengan Kecemasan Anak Prasekolah yang Mengalami Hospitalisasi
}

\author{
${ }^{1)}$ ENDANG, ${ }^{2)}$ LISWARYANA \\ 1) Program Studi DIII Kebidanan \\ 2) Mahasiswa Program Studi S1 Keperawatan \\ Universitas Pahlawan Tuanku Tambusai \\ Email: ${ }^{1}$ endang.mayasari85@yahoo.com, ${ }^{2}$ liswaryana@gmail.com
}

Article Received: 17-07-2018

Published Article: 07-11-2018

DOI: https://doi.org/10.29313/ga.v2i1.3856

\begin{abstract}
An increasing number of children who are hospitalized are at risk of an increase in the population of children who experience anxiety. The purpose of this study was to determine the factors associated with the anxiety of preschoolers who had undergone hospitalization in the children's room at Bangkinang Hospital in 2016. The design used in this study was Analytical with Cross Section design. The sample in this study were preschool children who were treated in the children's room of Bangkinang Hospital totaling 30 respondents with the Total Sampling method. The data collection tool used was a questionnaire with univariate and bivariate analysis. The results showed that there were two factors that influenced anxiety that showed related results: hospital environment $p=0.01$ ( $p 50.05$ ), health workers $p=0.006$ ( $p 50.05$ ), unrelated, namely family support $p=0.7$ ( $p 50.05$ ). It is expected that health workers can provide therapy to children to reduce anxiety.
\end{abstract}

Keywords: Preschoolers, Hospitalisation, Anxiety, Family Support.

\begin{abstract}
Abstrak
Peningkatan jumlah anak yang dirawat di rumah sakit, beresiko terjadi peningkatan populasi anak yang mengalami kecemasan. Tujuan penelitian ini untuk mengetahui faktor-faktor yang berhubungan dengan kecemasan anak prasekolah yang mengalami hospitalisasi di ruangan anak RSUD Bangkinang tahun 2016. Desain yang digunakan pada penelitian ini adalah Analitik dengan rancangan Cross Sectiona. Sampel dalam penelitian ini adalah anak prasekolah yang dirawat diruangan anak RSUD Bangkinang berjumlah 30 responden dengan metode Total Sampling. Alat pengumpulan data yang digunakan berupa kuesioner dengan analisa univariat dan bivariat. Hasil penelitian menunjukkan dari beberapa faktor yang mempengaruhi kecemasan yang menunjukkan hasil yang berhubungan ada dua: lingkungan rumah sakit $p=0,01$ ( $p$ > $0,05)$, tenaga kesehatan $p=0,006(p>0,05)$, yang tidak berhubungan yaitu dukungan keluarga $p=0,7(p>0,05)$. Diharapkan bagi tenaga kesehatan dapat memberikan terapi kepada anak untuk mengurangi kecemasan.
\end{abstract}

Kata Kunci: Anak Prasekolah, Hospitalisai, Kecemasan, Dukungan Keluarga.

\section{Pendahuluan}

Periode prasekolah adalah periode antara usia 3-5 tahun. Ini adalah waktu kelanjutan pertumbuhan dan perkembangan. Pertumbuhan fisik terus menjadi jauh lebih lambat dibandingkan dengan tahun-tahun sebelumnya. Peningkatan perkembangan kognitif, bahasa, dan psikososial penting selama periode prasekolah (Kyle dan Carman, 2014).

Anak merupakan individu yang berada dalam satu rentang perubahan perkembangan yang dimulai dari bayi hingga remaja. Anak diartikan sebagai seorang yang berusia 
kurang dari delapan belas tahun dalam masa tumbuh kembang dengan kebutuhan khusus baik kebutuhan fisik, psikologis, sosial, dan spiritual (Hidayat, 2008).

Hospitalisasi merupakan pengalaman penuh stres baik bagi anak maupun keluarganya (Nursalam, 2005). Hospitalisasi merupakan suatu proses yang menjadi alasan yang berencana atau darurat, mengharuskan anak untuk tinggal dirumah sakit, menjalani terapi pengobatan dan perawatan sampai pemulangannya kembali kerumah (Supartini, 2004).

Hospitalisasi yang terjadi pada anak merupakan pengalaman yang menggangu kehidupan anak yang dapat juga menyebabkan kecemasan pada anak. Stres akibat hospitalisasi akan menimbulkan perasaan tidak nyaman pada anak. Reaksi kecemasan pada anak dapat timbul karena perpisahan, kehilangan, perlukaan tubuh dan rasa nyeri. Perasaan tersebut dapat timbul karena menghadapi sesuatu yang baru dan belum pernah dialami sebelumnya, rasa tidak aman dan tidak nyaman, perasaan kehilangan sesuatu yang biasa, dan sesuatu yang dirasakan menyakitkan. Tidak hanya anak, stress selama dalam perawatan orang tua menjadi stres pula, dan stres orang tua akan membuat tingkat stres anak semakin meningkat (Supartini, dalam Rahmawati, 2004).

Banyak anak menolak diajak ke rumah sakit, apalagi menjalani rawat inap dalam jangka waktu yang lama. Peralatan medis yang terlihat bersih dirasakan cukup menyeramkan bagi anak-anak. Begitu juga dengan bau obat yang menyengat dan penampilan para staf rumah sakit dengan baju putihnya yang terkesan angker. Untuk mengurangi ketakutan anak yang harus mengalami rawat inap di rumah sakit dapat dilakukan beberapa cara salah satunya adalah melakukan permainan dokterdokteran dengan membiarkan anak bereksplorasi dengan alat-alat kedokteran, seperti jarum suntik dan stetoskop. Anak berperan menjadi dokter, sementara anak lain atau orang tua menjadi pasiennya (Imam 2008, dalam Rahmawati 2008).

Angka kesakitan anak di Indonesia berdasarkan Survei Kesehatan Nasional (SUSENAS) tahun 2010 di daerah perkotaan menurut kelompok usia 0-4 tahun sebesar $25,8 \%$, usia 5-12 tahun sebanyak $14,91 \%$, usia 13-15 tahun sekitar 9,1\%, usia 16-21 tahun sebesar 8,13\%. Angka kesakitan anak usia 0-21 tahun apabila dihitung dari keseluruhan jumlah penduduk adalah $14,44 \%$. Menjalani perawatan di rumah sakit dapat berpengaruh terhadap kondisi fisik dan psikologi anak (Apriany, 2013).

Data satu tahun terakhir ruangan rawat inap anak RSUD Bangkinang jumlah anak prasekolah (3-6) pada tahun 2015 sejumlah 149 anak usia 3-6 tahun. Anak umur 3 tahun berjumlah 88 anak, umur 4 tahun berjumlah 81 anak, umur 5 tahun berjumlah 36 anak, dan umur 6 tahun berjumlah 23 anak. Survei yang dilakukan diruangan anak bahwa anak sering mengalami kecemasan ketika dirawat. Anak menjadi sering gelisah, rewel dan harus ditemani ketika menjalani proses perawatan.

Berdasarkan wawancara dan survei yang dilakukan pada orang tua anak dan perawat, bahwa yang menyebebkan kecemasan pada anak yakni dari tindakan medis, seperti minum obat, jarum suntik dan lainnya. Dengan adanya ruangan bermain untuk anak, dapat mengurangi kecemasan pada anak yang dirawat inap. Data diketahui terdapat 7 anak usia 3-6 tahun (prasekolah) yang dirawat ruangan anak pada Bulan Januari 2016, dan sebagian besar anak dari seluruh pasien anak usia 3-6 tahun (prasekolah) menunjukkan perilaku cemas dan takut terhadap tindakan keperawatan, seperti pada saat dilakukan pemeriksaan tanda-tanda vital, sebagian besar anak yang dirawat memberikan respon rewel, takut, merapatkan diri pada orang tua/keluarga, serta menangis.

Berdasarkan uraian diatas, maka peneliti tertarik melakukan penelitian dengan judul "Faktor-faktor yang berhubungan dengan kecemasan anak prasekolah yang mengalami hospitalisasi diruangan anak RSUD Bangkinang.

\section{Metode Penelitian}

\section{Desain Penelitian}

Jenis penelitian ini adalah Analitik dengan rancangan Cross Sectional. Penelitian ini dilakukan untuk menentukan faktor-faktor yang berhubungan dengan kecemasan anak prasekolah yang mengalami hospitalisasi diruangan rawat inap anak RSUD Bangkinang tahun 2016. 


\section{Lokasi dan Waktu Penelitian}

Penelitian ini dilakukan diruangan rawat inap anak RSUD Bangkinang. Waktu penelitian ini dilakukan pada bulan Juni juli 2016

\section{Populasi}

Populasi merupakan seluruh subyek dengan karakteristik tertentu yang akan diteliti (Hidayat, 2011) pada penelitian ini yang menjadi populasi adalah semua anak prasekolah yang dirawat inap diruangan Anak di RSUD Bangkinang adalah sebanyak 30 pasien anak (berdasarkan data jumlah anak yang dirawat inap dalam tiga bulan terakhir Januari sampai Maret 2016).

\section{Sampel}

Pengambilan sampel pada penelitian ini menggunakan teknik Sampel merupakan bagian populasi yang akan diteliti atau sebagian jumlah dari karakteristik yang dimiliki oleh populasi (Hidayat, 2011). Besarnya sampel dalam penelitian ini yakni 30 pasien anak prasekolah (3-6 tahun) yang sedang menjalani hospitalisasi di RSUD Bangkinang dan memenuhi kriteria inklusi ataupn kriteria ekslusi yang ditetapkan oleh peneliti.

\section{Alat Pengumpulan Data}

Data karakteristik responden terdiri dari data nama ibu dan anak, usia anak, pekerjaan ibu, jenis kelamin anak. Data ini diperoleh dengan mengajukan pertanyaaan terbuka kepada ibu responden. Untuk dukungan orang tua diukur dengan menggunakan pernyataan dalam berbentuk dishotomose choise. Untuk tindakan medis diukur dengan menggunakan pernyataan dalam berbentuk dishotomose choise. Untuk tindakan diukur dengan menggunakan pernyataan dalam berbentuk dishotomose choise. Alat ukur kecemasan ini memnggunakan alat ukut T-MAS (taylor manifest anxiety scale).

\section{Analisa Data}

Dalam penelitian ini peneliti menganalisa data secara univariat dan bivariat menggunakan uji Chi Square

\section{Hasil dan Pembahasan}

\section{Hasil Penelitian}

\section{Analisis Univariat}

Berdasarkan pengumpulan data umum melalui penyebaran kuesioner terhadap 30 responden di di ruangan RSUD Bangkinang distribusi frekuensi berdasarkan dukungan keluarga di ruangan anak RSUD Bangkinang dari 30 pasien anak, sebagian besar responden mendapatkan dukungan keluarga yaitu

20 orang $(66,7 \%)$. distribusi frekuensi berdasarkan lingkungan rumah sakit di ruangan anak RSUD Bangkinang dari 30 pasien anak, sebagian besar responden anak berada dilingkungan rumah sakit yakni baik yaitu 18 orang $(60,0 \%)$. distribusi frekuensi berdasarkan petugas kesehatan di ruangan anak RSUD Bangkinang dari 30 pasien anak, sebagian besar responden cemas dengan petugas kesehatan yaitu 22 orang (73,3\%).

\section{Analisa Bivariat}

Analisis bivariat adalah analisis yang digunakan untuk melihat hubungan antara variabel bebas dengan variabel terikat. Uji yang dilakukan adalah uji statistik dengan Chi-square. Suatu variabel independen dinyatakan mempunyai hubungan yang bermakna jika hasil uji statistiknya memperoleh nilai $p<0,05$ dengan derajat kepercayaan $95 \%$ maka didapat hasil sebagai berikut:

\section{Hubungan Dukungan Keluarga den- gan Kecemasan Anak Prasekolah yang Mengalami Hospitalisasi Di Ru- ang Anak RSUD Bangkinang Tahun 2016}

Berdasarkan hasil penelitian dapat dilihat bahwa dari 20 anak yang mendapatkan dukungan keluarga, terdapat 8 anak (40\%) yang mengalami cemas sedang, sedangkan dari 10 anak yang tidak mendapatkan dukungan keluarga terdapat 5 anak (50\%) yang mengalami cemas sedang. Berdasarkan $u j i$ statistik diperoleh nilai $p=0,7(p>0,05)$, dengan derajat kemaknaan $(\alpha=0,05)$. Ini berarti tidak terdapat hubungan yang signifikan antara dukungan keluarga dengan kecemasan anak prasekolah yang mengalami hospitalisasi di Ruang Anak RSUD Bangkinang Tahun 2016. 


\section{Hubungan Lingkungan Rumah sakit dengan Kecemasan Anak Prasekolah yang Mengalami Hospitalisasi Di Ru- ang Anak RSUD Bangkinang Tahun 2016}

Berdasarkan hasil penelitian dapat dilihat bahwa dari 18 anak yang berada dilingkungan rumah sakit yang baik, terdapat 9 anak (50\%) yang mengalami cemas sedang, sedangkan dari 12 anak yang kurang nyaman berada dilingkungan rumah sakit terdapat 5 anak (50\%) yang tidak mengalami cemas. Berdasarkan uji statistik diperoleh nilai $\mathrm{p}=$ $0,01$ ( $p<0,05)$, dengan derajat kemaknaan $(a=0,05)$. Ini berarti terdapat hubungan yang signifikan antara lingkungan rumah sakit dengan kecemasan anak prasekolah yang mengalami hospitalisasi di Ruang Anak RSUD Bangkinang Tahun 2016.

\section{Hubungan Petugas Kesehatan den- gan Kecemasan Anak Prasekolah yang Mengalami Hospitalisasi Di Ru- ang Anak RSUD Bangkinang Tahun 2016}

Berdasarkan tabel 4.10 dapat dilihat bahwa dari 22 anak yang takut kepada petugas kesehatan, terdapat 8 anak (50\%) yang mengalami cemas sedang, sedangkan dari 8 anak yang tidak takut kepada petugas kesehatan terdapat 4 anak (50\%) yang tidak mengalami cemas. Berdasarkan uji statistik diperoleh nilai $p=0,006$ ( $p<0,05)$, dengan derajat kemaknaan $(a=0,05)$. Ini berarti terdapat hubungan yang signifikan antara petugas kesehatan dengan kecemasan anak prasekolah yang mengalami hospitalisasi di Ruang Anak RSUD Bangkinang Tahun 2016.

\section{Pembahasan}

\section{Analisa Bivariat}

Hubungan Dukungan Keluarga dengan kecemasan anak prasekolah yang mengalami hospitalisasi di Ru- ang anak RSUD Bangkinang tahun 2016

Berdasarkan hasil penelitian dapat dilihat bahwa dari 20 anak yang mendapatkan dukungan keluarga, terdapat 8 anak (40\%) yang mengalami cemas sedang, sedangkan dari 10 anak yang tidak mendapatkan dukungan keluarga terdapat 5 anak (50\%) yang mengalami cemas sedang. Berdasarkan uji statistik diperoleh nilai $p=0,7(p<0,05)$, dengan derajat kemaknaan $(a=0,05)$. Ini berarti tidak terdapat hubungan yang signifikan antara dukungan keluarga dengan kecemasan anak prasekolah yang mengalami hospitalisasi di Ruang Anak RSUD Bangkinang Tahun 2016.

Menurut asumsi peneliti anak yang mendapatkan dukungan keluarga tetapi masih mengalami cemas ringan dalam menjalankan hospitalisasi disebabkan karena sebagian besar anak berumur 3 tahun sehingga semakin muda usia anak, maka akan semakin sulit bagi anak untuk menyesuaikan diri dengan lingkungan sehingga anak tetap mengalami cemas sedang.

\section{Hubungan Lingkungan rumah sakit dengan kecemasan anak prasekolah yang mengalami hospitalisasi di Ru- ang anak RSUD Bangkinang tahun 2016}

Dari hasil penelitian dapat diketahui bahwa dari 18 anak yang berada dilingkungan rumah sakit baik, terdapat 9 anak (50\%) yang mengalami cemas sedang, sedangkan dari 12 anak yang kurang nyaman dilingkungan rumah sakit terdapat 5 anak $(50 \%)$ yang tidak mengalami cemas. Berdasarkan uji statistik diperoleh nilai $p=0,01$ ( $p<0,05)$, dengan derajat kemaknaan $(a=0,05)$. Ini berarti terdapat hubungan yang signifikan antara lingkungan rumah sakit dengan kecemasan anak prasekolah yang mengalami hospitalisasi di Ruang Anak RSUD Bangkinang Tahun 2016.

Menurut asumsi peneliti, anak yang berada dilingkungan rumah sakit yang merasa asing dalam proses penyembuhan mengalami cemas sedang karena perawat kurang bersosialisasi dengan anak sebelum memberikan tindakan keperawatan sehingga anak berfikir bahwa perawat adalah orang yang cukup menyeramkan bagi anak.

Hubungan Petugas Kesehatan dengan kecemasan anak prasekolah yang mengalami hospitalisasi di Ru- ang anak RSUD Bangkinang tahun 2016

Dari hasil penelitian dapat diketahui bahwa dari 22 anak yang takud kepada petugas kesehatan, terdapat 8 anak (50\%) yang mengalami cemas sedang, sedangkan dari 8 anak yang tidak takut kepada petugas kesehatan terdapat 4 anak (50\%) yang tidak 
mengalami cemas. Berdasarkan uji statistik diperoleh nilai $p=0,006(p<0,05)$, dengan derajat kemaknaan $(a=0,05)$. Ini berarti terdapat hubungan yang signifikan antara petugas kesehatan dengan kecemasan anak prasekolah yang mengalami hospitalisasi di Ruang Anak RSUD Bangkinang Tahun 2016.

Menurut asumsi peneliti anak yang mengalami kecemasan disebaban karena petugas kesehatan memiliki baju putih membuat anak merasa cemas dan takut dengan petugas kesehatan.

Menurut Supartini (2004), peran perawat dalam meminimalkan kecemasan pada anak saat hospitalisasi sangatlah penting. Salah satu tindakan yang penting yang dapat dilakukan untuk mengurangi kecemasan adalah melibatkan orang tua untuk berperan aktif dalam perawatan anak, salah satunya dengan membolehkan orang tua untuk tinggal bersama anak selama 24 jam, hal ini merupakan salah satu bagian dari pelayanan Atraumatic care

\section{Kesimpulan}

Dari penelitian dan pembahasan pada bab sebelumnya tentang "faktor-faktor yang berhubungan dengan kecemasan anak prasekolah yang mengalami hospitalisasi diruangan anak RSUD Bangkinang tahun 2016" dapat diambil kesimpulan: 1) Lebih dari separoh anak prasekolah yang dirawat diruangan anak RSUD Bangkinang tahun 2016 mengalami kecemasan. 2) Tingkat kecemasan anak prasekolah yang dirawat diruangan anak RSUD bangkinang tahun 2016 sebagian besar pada kategori kecemasan sedang.

3) Tidak ada hubungan antara dukungan keluarga dengan kecemasan pada anak prasekolah yang mengalami hospitalisasi. 4) Terdapat hubungan faktor lingkungan rumah sakit dengan kecemasan anak prasekolah yang mengalami hospitalisasi. 5) Terdapat hubungan faktor tenaga kesehatan dengan kecemasan anak prasekolah yang mengalami hospitalisasi.

\section{Saran}

\section{Aspek teoritis}

Diharapkan penelitian ini dapat menjadi salah satu informasi ilmiah dalam menurunkan kecemasan anak yang di hospitalisasi dan bagi penelitian lain yang tertarik dengan penelitian ini dapat menjadikan penelitian ini sebagai acuan dan menyusun hipotesis baru sebagai rancangan penelitian berikutnya.

\section{Aspek praktis}

Hasil penelitian ini diharapkan dapat memberikan perbaikan kebijakan dalam mengurangi kecemasan anak yang di hospitalisasi, begitu juga bagi tenaga kesehatan untuk dapat memberikan terapi untuk mengurangi kecemasan anak yang dihospitalisasi sehingga dapat menurunkan kecemasan anak.

\section{Daftar Pustaka}

Ade. (2011). Asuhan Keperawatan Jiwa. Yogyakarta; Nuha Medika.

Budiarto. (2013). Biostatistik untuk Kedokteran Kesehatan Masyarakat. Jakarta; EGC.

Hidayat. (2008). Pengantar Ilmu Keperawatan Aanak 1. Jakarta; Salemba Medika

(2011). Metode Penelitian Keperawatan Tehnik Analisa Data. Edisi 1. Jakarta; Salemba Medika.

Mariam. (2008). Faktor-faktor yang Berhubungan dengan Tingkat Kecemasan

Orang Tua Terkait Hospitalisasi Anaka Usia

Toddler. Skripsi. Tidak diterbitkan. FIKKES Notoatmodjo. (2010). Metodologi Penelitian Kesehatan. Jakarta; Rineka Cipta.

Notoatmojo. (2010). Metodologi Penelitian Kesehatan. Jakarta; Rineka Cipta.

Nursalam. (2013). Metodologi Penelitian IImu Keperawatan. Edisi 3. Jakarta; Salemba Medika.

Putra. (2014). Keperawatan Anak \& Tumbuh Kembang. Yogyakarta; Nuha Medika.

Rahmawati. (2008). Pengaruh Terapi Bermain Terhadap Tingkat Kooperatif Selama Menjalani Perawatan pada Anak Usia Prasekolah. Skripsi. Tidak diterbitkan. STIKes Surya Global Yogyakarta.

Rahmawati, Murniasih. (2007). Hubungan Dukungan Keluarga dengan Tingkat Kecemsan Akibat Hospitalisasi pada Anak Uisa Prasekolah. Skripsi. Tidak diterbitkan. STIKes Surya Global Yogyakarta.

Sukarmin. (2009). Asuhan Keperawatan pada Anak. Yogyakarta; Graha ilmu.

(2005). Asuhan Keperawatan Bayi dan Anak. Edisi 1. Jakarta; Salemba Medika.

S u partini. ( 2004 ). Kons epDas a $r$ Keperawatan Anak. Jakarta; EGC. http://

karyatulisilmiah.com/hospitalisasi.pada. anak.usia. 
ENDANG, LISWARYANA, Faktor-Faktor yang Berhubungan dengan Kecemasan Anak Prasekolah yang Me...

Suriadi \& Rita Yuliani. (2006). Asuhan

Keperawatan pada Anak. Jakarta.

Wong. (2003). Keperawatan Pediatrik. Edisi

4. Jakarta; EGC.

Wong, dkk. (2003). Keperawatan Pediatrik.

Edisi 4. Jakarta; EGC.

Wong. (2008). Buku Ajar Keperawatan

Pediatrik. Edisi 6. Jakarta; EGC. 